\title{
Nuances in the Management of Hand and Wrist Injuries in Athletes
}

Editor

SANJEEV KAKAR

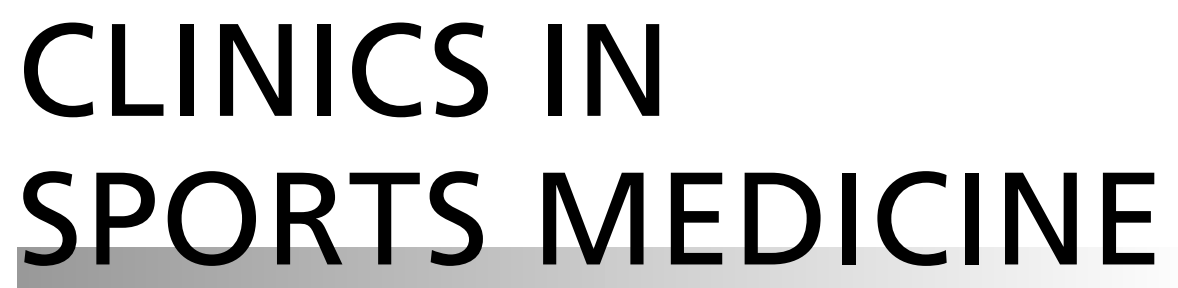

www.sportsmed.theclinics.com

Consulting Editor

MARK D. MILLER

April 2020 • Volume 39 - Number 2 